\title{
Nerve conduction velocity in man: influence of glucose, somatostatin and electrolytes
}

\author{
L. Orskov ${ }^{2}$, M.Worm ${ }^{3}$, O.Schmitz ${ }^{1}$, A.Mengel ${ }^{2}$, P.Sidenius ${ }^{4}$ \\ ${ }^{1}$ Department of Medicine M (Diabetes and Endocrinology) \\ ${ }^{2}$ Institute of Experimental Clinical Research, \\ ${ }^{3}$ Department of Neurophysiology, \\ ${ }^{4}$ Department of Neurology, University Hospital of Aarhus, Denmark
}

Summary Insufficient metabolic control in diabetes mellitus is associated with a reversible reduction in nerve conduction velocity, but the mechanism behind this phenomenon is unknown. To examine the effect of acute hyperglycaemia on nerve conduction eight non-diabetic men (20-49 years of age) with no signs of peripheral neuropathy were studied before and after $3 \mathrm{~h}$ of hyperglycaemic clamping (plasma glucose $\approx 15 \mathrm{mmol} / \mathrm{l}$ ), while insulin secretion was suppressed by somatostatin [Study 1]. Nerve conduction velocity, as determined in the proximal part of the median nerve, fell by $2.8 \pm 3.0 \mathrm{~m} / \mathrm{s}$ ( $2 p$-value: 0.033$)$. However, during euglycaemic clamping (plasma glucose $\approx 5 \mathrm{mmol} / \mathrm{l}$ ) in five non-diabetic men (19-38 years of age) infused solely with somatostatin [Study 2], a comparable decrement in nerve conduction velocity was found $(1.7 \pm 1.3 \mathrm{~m} / \mathrm{s}, 2 p$-value:
0.043). In both studies relative hypoinsulinaemia was present. Serum-sodium decreased significantly $(143 \pm 1 \mathrm{mmol} / \mathrm{l}$ vs $137 \pm 1 \mathrm{mmol} / \mathrm{l}$ [Study 1] and $143 \pm 1 \mathrm{mmol} / 1$ vs $142 \pm 2 \mathrm{mmol} / 1$ [Study 2 ]), while serum-potassium increased. In conclusion, the slight but significant reduction in nerve conduction velocity observed in both studies appears to be correlated to electrolyte changes. However, an effect of hypersomatostatinaemia or the hormonal changes associated with this cannot be excluded, while short-term hyperglycaemia per se seems to be without effect on nerve conduction velocity. [Diabetologia (1994) 37: 1216-1220]

Key words Diabetes, diabetic neuropathy, electrolytes, hyperglycaemia, nerve conduction, somatostatin.
Clinical neuropathy is a major complication of longterm diabetes mellitus $[1,2]$. Assessment of neuropathy is often made by measuring nerve conduction velocity (NCV), which has been found to be reduced in diabetic patients with and without clinical neuropathy $[3,4]$. In the late stage, diabetic neuropathy is characterized by axonal degeneration, demyelination and fibre loss [5]. In early diabetes a modest and partly reversible decrease in NCV is seen. This condition appears to be associated with metabolic control

Received: 10 January 1994

and in revised Form: 25 May 1994

Corresponding author: Dr. L. Ørskov, Department of Hepatology V, Aarhus Kommunehospital, DK-8000 Aarhus C, Denmark

Abbreviations: NCV, Nerve conduction velocity.
[6], but the cause of this decrease is unknown. Even in diabetes of long duration there seems to be a reversible metabolic component superimposed on the late structural neuropathy, as restoration of nearnormoglycaemia improves nerve conduction $[4,7]$. The present study was performed to gain further insight into the pathogenesis of nervous abnormalities in diabetes by examining the effect of hyperglycaemia on NCV while other hormonal and metabolic variables were controlled or closely monitored.

\section{Materials and methods}

Subjects and experimental design. Two different study protocols were employed (Fig.1). In a hyperglycaemic study (Study 1), eight healthy lean men, with a mean age of $34 \pm 9$ years (range 20-49 years) were studied. All participants had been fasting since 24.00 hours. At 08.00 hours ( $\mathrm{t}$ : $-60 \mathrm{~min}$ ), 
Experimental Design

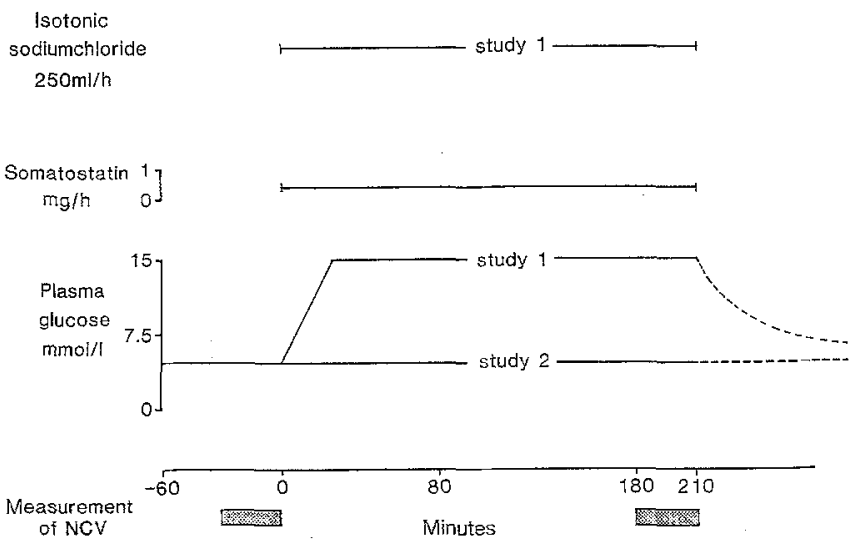

Fig. 1. Plasma glucose was clamped at either $15 \mathrm{mmol} / \mathrm{l}$ (hyperglycaemic study $\approx$ Study 1 ) or $5 \mathrm{mmol} / 1$ (euglycaemic study $\approx$ Study 2$)$ with infusion of somatostatin $(400 \mu \mathrm{g} / \mathrm{h})$. In Study 1 sodium chloride was also infused. Nerve conduction velocity was measured before $(-30-0 \mathrm{~min})$ and at the end (180-210 min) of the clamps

two intravenous cannulae were inserted. One placed in an arterialized hand vein was used for blood sampling, the other for infusions. Proximal and distal sensory NCV, proximal motor NCV and distal motor latency were determined in the median nerve twice, i.e., at the start of the experiment $(-30 \mathrm{~min}$ to $0 \mathrm{~min}$ ) and after $3 \mathrm{~h}$ of hyperglycaemia (180 to $210 \mathrm{~min})$. At 09.00 hours $(t=0)$ plasma glucose was acutely raised to $15 \mathrm{mmol} / \mathrm{l}$ (Fig. 1) and then maintained at this level by a variable glucose infusion $(200 \mathrm{~g} / \mathrm{l})$. To suppress endogenous insulin secretion, somatostatin (Ferring AB, Malmö, Sweden) was infused at a rate of $400 \mu \mathrm{g} / \mathrm{h}$. Moreover, isotonic sodium chloride was infused $(250 \mathrm{ml} / \mathrm{h})$ to reduce the hyperglycaemia-induced increase in serum osmolality.

Plasma glucose was measured every $5 \mathrm{~min}$ by a glucose analyser (Beckman Instruments, Palo Alto, Calif., USA). Serum-insulin was measured as shown in Figure 2, while blood for determination of serum-electrolytes, osmolality, creatinine, urea, bicarbonate, protein, C-peptide and growth hormone was drawn at $-60,0,60,180$ and $210 \mathrm{~min}$. As no significant fluctuations in blood chemistry were seen to occur before the infusion the values at t: $0 \mathrm{~min}$ were used as the before-value. The after-value was defined as the mean value of the measurements $t: 180$ to $t: 210$, i.e., the period during which nerve conduction was evaluated. In the euglycaemic study (Study 2) five healthy lean men with a mean age of $28 \pm 8$ years (range 19-38 years) were examined according to the same study protocol as described above, the only differences being that plasma glucose was clamped at euglycaemia $(5 \mathrm{mmol} / \mathrm{l})$ and no sodium chloride was infused.

None of the participants had symptoms or signs of peripheral neuropathy. All had given informed consent and the study was approved by the Regional Ethical Committee.

Nerve conduction measurement. For stimulation of sensory fibres surface electrodes were placed on digits I and III. Recording needle electrodes were placed near the left median nerve at the wrist and elbow. The needles were left in place during the experiment. The distal sensory NCV were measured from digit I to the wrist and from digit III to the wrist. The proximal sensory NCV was measured from wrist to elbow after stimulating at the digits. The values given in Table 2 are the mean between values obtained by stimulating at digits I and III, respec-
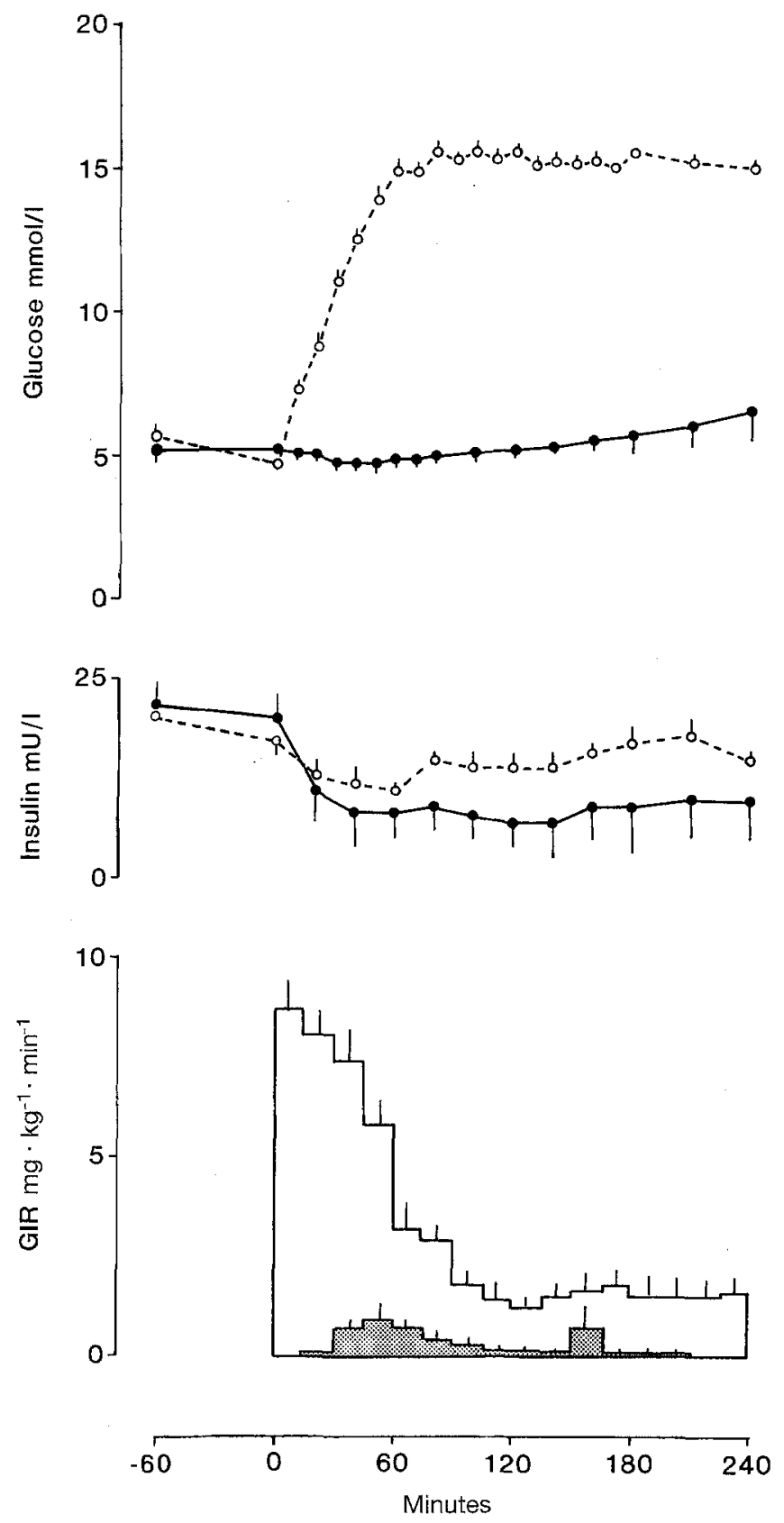

Fig. 2. Plasma glucose, serum insulin and rate of glucose infusion (GIR) during a hyperglycaemic $\bigcirc$ and euglycaemic clamp study (O) with infusion of somatostatin

Values are mean $\pm \mathrm{SEM}$

tively. The motor latency and the motor NCV were measured by stimulating with needle electrodes placed at wrist and elbow, and recording from a needle electrode placed in the thenar.

Analytical methods. Plasma glucose was determined by a glucose oxidase method, and serum growth hormone and insulin as previously described [8]. Serum C-peptide was assayed employing a commercial kit (Immunonuclear Corp., Stillwater, Minn., USA). 
Table 1. Concentration of glucose in plasma, osmolality of the serum, and concentration of creatinine, carbamide, $\mathrm{HCO}^{3}$, protein, hormones and inorganic ions in serum before and after $3 \mathrm{~h}$ glycaemic clamping (Study $1 \approx 15 \mathrm{mmol} / \mathrm{l}$, Study $2 \approx 5 \mathrm{mmol} / \mathrm{l}$ )

\begin{tabular}{|c|c|c|c|c|c|c|c|c|c|}
\hline \multirow{3}{*}{$\begin{array}{l}\text { Group } \\
\text { No. }\end{array}$} & \multirow[t]{3}{*}{ Unit } & \multicolumn{4}{|l|}{ Study 1} & \multicolumn{4}{|l|}{ Study 2} \\
\hline & & \multicolumn{4}{|c|}{ Eight subjects } & \multicolumn{4}{|c|}{ Five subjects } \\
\hline & & Before & After & Change & $2 p$-value & Before & After & Change & $2 p$-value \\
\hline Glucose & $\mathrm{mmol} / \mathrm{l}$ & $5.1 \pm 0.5$ & $15.3 \pm 0.2$ & $10.2 \pm 0.6$ & $<<0.001$ & $5.1 \pm 0.3$ & $5.8 \pm 1.5^{b}$ & $0.7 \pm 1.5^{\mathrm{b}}$ & N.S. \\
\hline Osmolality & $\mathrm{mOSM} / \mathrm{kg}$ & $283 \pm 2$ & $288 \pm 3$ & $4.9 \pm 1.5$ & $<<0.001$ & $288 \pm 4^{b}$ & $288 \pm 2$ & $-0.4 \pm 2.3^{b}$ & N.S. \\
\hline Creatinine & $\mathrm{mmol} / \mathrm{l}$ & $89 \pm 4$ & $88 \pm 5$ & $-0.8 \pm 3.3$ & N.S. & $94 \pm 7$ & $92 \pm 4$ & $-2.3 \pm 2.6$ & N.S. \\
\hline Carbamide & $\mathrm{mmol} / \mathrm{l}$ & $4.3 \pm 0.7$ & $3.7 \pm 0.6$ & $-0.59 \pm 0.16$ & $<<0.001$ & $4.5 \pm 0.5$ & $4.3 \pm 0.5$ & $-0.24 \pm 0.11^{\mathrm{a}}$ & 0.0029 \\
\hline $\mathrm{HCO}_{3}$ & $\mathrm{mmol} / 1$ & $24 \pm 1$ & $23 \pm 1$ & $-1.3 \pm 1.6$ & N.S. & $26 \pm 2$ & $25 \pm 1^{\mathrm{a}}$ & $-1.2 \pm 1.3$ & N.S. \\
\hline Protein & $\mathrm{g} / 1$ & $68 \pm 4$ & $61 \pm 3$ & $-7.4 \pm 2.2$ & $<<0.001$ & $65 \pm 4$ & $65 \pm 3^{\mathrm{a}}$ & $0.5 \pm 2.8^{\mathrm{b}}$ & N.S. \\
\hline Insulin & $\mathrm{mU} / \mathrm{l}$ & $14.8 \pm 6.1$ & $17.0 \pm 4.7$ & $2.2 \pm 8.2$ & N.S. & $19.6 \pm 5.5$ & $9.5 \pm 11.1$ & $-10.1 \pm 9.0^{\mathrm{a}}$ & $(0.066)$ \\
\hline C-peptide & $\mu \mathrm{g} / 1$ & $1.16 \pm 0.31$ & $1.28 \pm 0.26$ & $0.12 \pm 0.32$ & N.S. & $1.84 \pm 0.93$ & $0.84 \pm 0.22^{b}$ & $-1.00 \pm 0.74^{b}$ & 0.039 \\
\hline $\begin{array}{l}\text { Growth } \\
\text { hormone }\end{array}$ & $\mu \mathrm{g} / 1$ & $1.40 \pm 0.63$ & $1.99 \pm 0.74$ & $0.59 \pm 0.51$ & 0.013 & $3.60 \pm 3.74$ & $2.37 \pm 1.22$ & $-1.23 \pm 4.05$ & N.S. \\
\hline Sodium & $\mathrm{mmol} / 1$ & $143 \pm 1$ & $137 \pm 3$ & $-5.8 \pm 2.2$ & $<0.001$ & $143 \pm 1$ & $142 \pm 2^{b}$ & $-1.5 \pm 0.7^{\mathrm{b}}$ & 0.0091 \\
\hline Potassium & $\mathrm{mmol} / 1$ & $4.30 \pm 0.32$ & $4.64 \pm 0.26$ & $0.34 \pm 0.25$ & 0.0064 & $4.16 \pm 0.23$ & $4.52 \pm 0.42$ & $0.36 \pm 0.54$ & N.S. \\
\hline Calcium & $\mathrm{mmol} / 1$ & $2.39 \pm 0.32$ & $2.19 \pm 0.12$ & $-0.20 \pm 0.07$ & $<0.001$ & $2.37 \pm 0.10$ & $2.38 \pm 0.09^{b}$ & $0.01 \pm 0.04^{\mathrm{b}}$ & N.S. \\
\hline Magnesium & $\mathrm{mmol} / \mathrm{l}$ & $0.84 \pm 0.06$ & $0.79 \pm 0.04$ & $-0.05 \pm 0.03$ & 0.0037 & $0.85 \pm 0.03$ & $0.85 \pm 0.05$ & $0.00 \pm 0.03^{\mathrm{a}}$ & N.S. \\
\hline Chloride & $\mathrm{mmol} / \mathrm{l}$ & $105 \pm 2$ & $104 \pm 2$ & $-0.8 \pm 1.6$ & N.S. & $106 \pm 2$ & $107 \pm 2$ & $0.9 \pm 0.9$ & N.S. \\
\hline Phosphate & $\mathrm{mmol} / 1$ & $1.17 \pm 0.19$ & $1.00 \pm 0.14$ & $-0.17 \pm 0.16$ & 0.019 & $0.97 \pm 0.11$ & $1.25 \pm 0.06^{\mathrm{b}}$ & $0.28 \pm 0.10^{\mathrm{b}}$ & 0.0034 \\
\hline
\end{tabular}

${ }^{a}$ Significantly different from the value of the hyperglycaemic group, $2 p$-value $<0.05$;

${ }^{b}$ Significantly different from the value of the hyperglycaemic group, $2 p$-value $<0.01$

Values are mean \pm SD

\section{Statistical analysis}

The values before and during hyperglycaemia were compared by Student's $t$-test for paired samples using a $5 \%$ limit of significance. A bivariate correlation analysis was used to analyse the connection between the different measurements. A stepwise regression analysis was used to analyse the dependence of the nerve conduction velocity of different factors. By each step the most significant factor was chosen and the remaining variation was correlated to the remaining factors.

\section{Results}

Glucose, hormones and electrolytes (Table 1, Fig. 2). Basal plasma-glucose levels were similar, at about $5 \mathrm{mmol} / \mathrm{l}$ in the two studies. After $3 \mathrm{~h}$ of hyperglycaemic clamping, plasma-glucose was $15.3 \pm 0.2 \mathrm{mmol} / \mathrm{l}$, while it remained at the basal level in study $2(5.8 \pm 1.5 \mathrm{mmol} / \mathrm{l})$.

Basal levels of serum-insulin, C-peptide and growth hormone were similar. As intended, somatostatin infusion prevented breakthrough of insulin secretion during hyperglycaemia, whereas during euglycaemia a definite suppression of insulin secretion followed upon somatostatin infusion, leading to relative hypoinsulinaemia in both studies.

Basal levels of serum-osmolality, -creatinine, -urea, -bicarbonate, -protein, -sodium, -potassium, -calcium, -magnesium, -chloride and -phosphate were similar in the two groups. In Study 1 , serum-osmolality increased by 4 mosmol during hyperglycaemia, whereas it was unaltered at basal level in Study 2.

In both studies serum-sodium decreased and -potassium increased. The changes were more pronounced in Study 1.

Changes were seen in the levels of some of the other inorganic ions as well, but none of these were similar in the two studies (Table 1).

Nerve function (Table 2). The thresholds of nerve stimulation showed no consistent changes. During hyperglycaemia NCV decreased by $2.5 \mathrm{~m} / \mathrm{s}$, though only the change of velocity in the proximal part of the median nerve obtained statistical significance. Correspondingly distal motor latency increased significantly and the amplitude of compound action potential decreased.

However, in the euglycaemic study comparable although less pronounced changes in NCV and action potential amplitude were seen.

Employing a bivariate regression analysis, a highly significant correlation was found between serum-sodium and NCV ( $r=0.78,2 p$-value $<0.01, n=13$ ) in the basal state, and a weaker, but still significant correlation ( $r=0.66,2 p$-value $<0.05, n=13$ ) was found between the final NCV measurement and the serumsodium during the same period. 
Table 2. Threshold, nervous conduction velocity, and amplitude of the action potential in different segments of the median nerve before and after $3 \mathrm{~h}$ glycaemic clamping (Study $1 \approx 15 \mathrm{mmol} / \mathrm{l}$, Study $2 \approx 5 \mathrm{mmol} / \mathrm{l}$ )

\begin{tabular}{|c|c|c|c|c|c|c|c|c|c|}
\hline \multirow{3}{*}{$\begin{array}{l}\text { Group } \\
\text { No. }\end{array}$} & \multirow[t]{3}{*}{ Unit } & \multicolumn{4}{|l|}{ Study 1} & \multicolumn{4}{|l|}{ Study 2} \\
\hline & & \multicolumn{4}{|c|}{ Eight subjects } & \multicolumn{4}{|c|}{ Five subjects } \\
\hline & & Before & After & Change & $2 p$-value & Before & After & Change & $2 p$-value \\
\hline $\begin{array}{l}\text { Threshold } \\
\text { Sensory } \\
\text { Motor }\end{array}$ & $\mu \mathrm{V}$ & $\begin{array}{l}3.23 \pm 1.50 \\
0.56 \pm 0.14\end{array}$ & $\begin{array}{l}3.11 \pm 1.26 \\
0.65 \pm 0.07\end{array}$ & $\begin{array}{l}-0.11 \pm 1.23 \\
0.09 \pm 0.10\end{array}$ & $\begin{array}{l}\text { N.S. } \\
0.047\end{array}$ & $\begin{array}{l}2.76 \pm 0.90 \\
0.55 \pm 0.11\end{array}$ & $\begin{array}{l}2.23 \pm 0.56 \\
0.60 \pm 0.08\end{array}$ & $\begin{array}{l}-0.53 \pm 1.23 \\
0.05 \pm 0.06\end{array}$ & $\begin{array}{l}\text { N.S. } \\
\text { N.S. }\end{array}$ \\
\hline $\begin{array}{l}\text { Conduction } \\
\text { Sens Dist } \\
\text { Sens Prox } \\
\text { Motor }\end{array}$ & $\begin{array}{l}\text { velocit } \\
\mathrm{m} / \mathrm{s} \\
\mathrm{m} / \mathrm{s} \\
\mathrm{m} / \mathrm{s}\end{array}$ & $\begin{array}{l}51.5 \pm 2.5 \\
62.9 \pm 3.0 \\
60.0 \pm 2.0\end{array}$ & $\begin{array}{l}49.1 \pm 4.8 \\
60.1 \pm 3.5 \\
57.8 \pm 3.1\end{array}$ & $\begin{array}{l}-2.4 \pm 3.1 \\
-2.8 \pm 3.0 \\
-2.3 \pm 3.8\end{array}$ & $\begin{array}{l}(0.064) \\
0.033 \\
\text { N.S. }\end{array}$ & $\begin{array}{l}52.7 \pm 2.6 \\
64.5 \pm 3.9 \\
61.2 \pm 6.2\end{array}$ & $\begin{array}{l}51.5 \pm 2.3 \\
62.8 \pm 3.4 \\
59.4 \pm 3.3\end{array}$ & $\begin{array}{l}-1.2 \pm 4.5 \\
-1.7 \pm 1.3 \\
-1.8 \pm 3.5\end{array}$ & $\begin{array}{l}\text { N.S. } \\
0.043 \\
\text { N.S. }\end{array}$ \\
\hline $\begin{array}{l}\text { Distal moto } \\
\text { Latency }\end{array}$ & $\mathrm{ms}$ & $3.3 \pm 0.2$ & $3.5 \pm 0.3$ & $0.13 \pm 0.14$ & 0.038 & $3.4 \pm 0.2$ & $3.5 \pm 0.2$ & $0.14 \pm 0.11$ & $(0.052)$ \\
\hline $\begin{array}{l}\text { Amplitude } \\
\text { Sens Dist } \\
\text { Sens Prox } \\
\text { Motor }\end{array}$ & $\begin{array}{l}\mu \mathrm{V} \\
\mu \mathrm{V} \\
\mathrm{mV}\end{array}$ & $\begin{array}{l}24.8 \pm 6.7 \\
9.5 \pm 3.7 \\
21.8 \pm 4.6\end{array}$ & $\begin{array}{l}22.5 \pm 7.2 \\
7.6 \pm 2.1 \\
17.6 \pm 5.6\end{array}$ & $\begin{array}{l}-2.3 \pm 3.7 \\
-1.9 \pm 2.3 \\
-4.2 \pm 4.5\end{array}$ & $\begin{array}{l}\text { N.S. } \\
(0.053) \\
0.034\end{array}$ & $\begin{array}{l}28.7 \pm 8.8 \\
10.0 \pm 1.8 \\
19.1 \pm 6.8\end{array}$ & $\begin{array}{l}26.6 \pm 7.6 \\
8.5 \pm 1.9 \\
18.0 \pm 3.3\end{array}$ & $\begin{array}{l}-2.1 \pm 1.5 \\
-1.5 \pm 0.7 \\
-1.1 \pm 3.8\end{array}$ & $\begin{array}{l}0.034 \\
0.011 \\
\text { N.S. }\end{array}$ \\
\hline
\end{tabular}

Values are mean \pm SD

The changes in plasma-glucose, serum-sodium, -calcium, -phosphate, -carbamide and -protein correlated closely ( $r= \pm 0.76-0.91,2 p$-value $<0.001)$, but no direct correlation to the change in nerve conduction was found. Neither was there any correlation between changes in serum-insulin and C-peptide vs changes in $\mathrm{NCV}$, but a relative hypoinsulinism prevailed in both studies.

\section{Discussion}

In the present study NCV was found to be reduced during short-term hyperglycaemic clamping $(3 \mathrm{~h})$ in healthy men. In a recent study on newly-diagnosed diabetic patients, NCV was found to correlate with glycated haemoglobin [9], whereas no correlation was found between acute blood glucose levels and NCV's. This was taken to indicate that electrophysiological disturbances are associated with sustained rather than transitory hyperglycaemia. No other parameters of metabolic disturbances were measured.

An association between nerve function and transient hyperglycaemia has previously been found in insulin-dependent diabetic patients $[10,11]$ as well as in animals [12]. Factors such as the level of glucose, insulin and increased osmolality have been speculated to be responsible, but the influence of other factors of known importance for nerve function, such as levels of serum-sodium and -potassium, has not previously been focused on.

In a study on healthy subjects, hyperglycaemia and concomitant hyperinsulinemia $(2 \mathrm{~h})$ was found to be associated with an increase in NCV [13]. Serum-electrolytes were essentially unchanged and it was hypothesized that either the increased serum-insulin level or the increased serum-osmolality were respon- sible for the increase NCV. In a follow-up study [11] on insulin-dependent diabetic subjects, $15 \mathrm{~min}$ of hyperglycaemia (+ $15 \mathrm{mmol} / \mathrm{l})$ was also found to augment NCV, whereas NCV decreased after $2 \mathrm{~h}$ of sustained hyperglycaemia. The immediate increase was ascribed to increased serum-osmolality, whereas the reduction following sustained hyperglycaemia was suggested to be due to the combination of hyperglycaemia, relative insulin depletion and increased serum-osmolality. The possible influence of changes in electrolytes was not evaluated.

In the present study, however, a reduced NCV was also found following $3 \mathrm{~h}$ of euglycaemic clamping with infusion of somatostatin alone. In both parts of the study blood chemistry was closely monitored. In the hyperglycaemic study the elevated plasma glucose level was accompanied by increased serum-osmolality and -potassium. Insulin was stable at basal, while serum-carbamide, -protein, -calcium and -sodium decreased. In the euglycaemic study serum-sodium and -carbamide decreased, whereas serum-potassium increased and serum-osmolality was unchanged.

The basal level of sodium was found to correlate closely with basal NCV, but although sodium decreased and potassium increased in both studies no correlation was found between the decrease in NCV and the changes in blood chemistry. This may be due to a possible delay in transmission of changes in blood chemistry to the endoneurium, so the blood levels do not accurately reflect the levels in the endoneurium. Because movement of sodium ions into the axon is responsible for the generation of the action potential, it is not surprising that changes in extracellular sodium can modify nerve conduction. Nevertheless, the finding of an association between serum-sodium and nerve conduction velocity still needs confirmation from further studies, but corroborate the hy- 
pothesis that short-term changes in nerve conduction associated with hyperglycaemia may be due to changes in metabolic state.

Another explanation may be that the changes in serum-electrolytes were not connected to the changes the reduction in NCV. As somatostatin was infused in both studies, it cannot be excluded that somatostatin per se may affect NCV. Somatostatin levels have previously been found to be elevated in diabetes [14], and a direct depressive action of somatostatin on nervous modalities has been described before [15]. However, such an effect of somatostatin on NCV remains hypothetical.

Likewise, insulin in itself cannot be ruled out as the causal factor. In the present study, relative hypoinsulinaemia was present in both protocols, as was the case in the study by Sindrup et al. [11] dealing with insulin-dependent diabetes and NCV. Diabetes has been suggested to induce disturbances by a reduction in nerve membrane $\mathrm{Na}+-\mathrm{K}+-$ ATPase activity [16]. A reduced (true or relative to glycaemic level) insulin level may reduce NCV by reducing $\mathrm{Na}+-\mathrm{K}+$ -ATPase activity [17]. Other, but undisclosed, metabolic effects of glycaemic clamps such as changes in non-esterified fatty acids, ketones, amino acids etc. might also have had an effect on NCV.

A standard requisite in drug trials of the effect on diabetic neuropathy include measurements of nerve conduction, and small changes (few $\mathrm{m} / \mathrm{s}$ ) have been interpreted as an improvement of the neuropathy. The results of the present study suggest that small changes can be due to changes in the metabolic state rather than changes in the degree of neuropathy. Thus, NCV is not a sufficient measure of the degree of neuropathy necessitating cautious interpretation of studies where nerve conduction velocity is used to assess degree of neuropathy.

Acknowledgements. We thank Ms. K. Aaris and Ms. I. Bisgaard for expert technical assistance and Ms. A. Andersen for excellent assistance in preparation of the manuscript.

\section{References}

1. Orchard TJ, Dorman JS, Maser RE et al. (1990) Prevalence of complications in IDDM by age and duration. Diabetes 39: $1116-1124$

2. The Diabetes Control and Complications Trial Research Group (1993) The effect of intensive treatment of diabetes on the development and progression of long-term compli- cations in insulin-dependent diabetes mellitus. N Engl J Med 329: 977-986

3. Downie AW, Newell DJ (1961) Sensory nerve conduction in patients with diabetes mellitus and controls. Neurology 11: $876-882$

4. Service FJ, Rizza RA, Daube JR et al. (1985) Near normoglycemia improved nerve conduction and vibration sensation in diabetic neuropathy. Diabetologia 28: 722-727

5. Dyck, PJ, Lais A, Karnes JL, O'Brien P, Rizza R (1986) Fibre loss is primary and multifocal in sural nerves in diabetic polyneuropathy. Ann Neurol 19: 425-439

6. Gregersen $G$ (1968) Variations in motor conduction velocity produced by acute changes of the metabolic state in diabetic patients. Diabetologia 4: 273-277

7. Graf RJ, Halter JB, Pfeifer MA, Halar E, Brozovich F, Porte D (1981) Glycemic control and nerve conduction abnormalities in non-insulin-dependent diabetic subjects. Ann Int Med 94: 307-311

8. Ørskov H, Thomsen AG, Yde H (1968) Wick-chromatography for rapid and reliable immunoassay of insulin, glucagon and growth hormone. Nature 219: 193-195

9. Allen C, Duck S, Sufit RL, Swick HM, DÁlessio DJ (1992) Glycemic control and peripheral nerve conduction in children and young adults after 5-6 mo of IDDM. Diabetes Care 15: 502-507

10. Troni W, Carta Q, Cantello R, Caselle MT, Rainero I (1984) Peripheral nerve function and metabolic control in diabetes mellitus. Ann Neurol 16: 178-183

11. Sindrup SH, Ejlertsen B, Gjessing H, Svendsen A, Frøland A (1989) Peripheral nerve function during hyperglycaemic clamping in insulin-dependent diabetic patients. Acta Neurol Scand 79: 412-418

12. Dyck PJ, Lambert EH, Windebank AJ et al. (1981) Acute hyperosmolar hyperglycaemia causes axonal shrinkage and reduced nerve conduction velocity. Exp Neurol 71: 507-514

13. Sindrup SH, Ejlertsen B, Gjessing H, Frøland A, Sindrup EH (1988) Peripheral nerve function during hyperglycaemic clamping in healthy subjects. Acta Neurol Scand 78: 141-145

14. Christensen SE, Schmitz O, Hansen AaP, Ørskov H (1986) Diurnal variations in plasma SLI in diabetic and non-diabetics. In: Dapti S, Gerich JE, Rosenthal J (eds). Proceedings of the 2nd International Symposium on Somatostatin. Academic Press, pp 254-258

15. Delfs JR, Dichter NA (1983) Effects of somatostatin on mammalian cortical neurons in culture: physiological activity and unusual dose response characteristics. J Neuroscience $3: 1176-1178$

16. Greene DA, Lattimer SA (1983) Impaired rat sciatic nerve sodium-potassium adenosine triphosphate in acute streptozotocin diabetes and its correction by dietary myo-inositol supplementation. J Clin Invest 72: 1058-1063

17. Clausen T, Kohn PG (1977) The effect of insulin on the transport of sodium and potassium in rat soleus muscle. $J$ Physiol 265: 19-42 